\title{
The Influence of Communication and Attachment with Peers on Adolescence Character in Rural Area
}

\author{
Zervina Rubyn Devi \\ Situmorang* \\ Department of Family and \\ Consumer Sciences, \\ Faculty of Human Ecology, \\ Bogor Agricultural University
}

\section{Dwi Hastuti}

Department of Family and Consumer Sciences, Faculty of Human Ecology, Bogor Agricultural University *Corresponding author: zervinaruby@ gmail.com

\section{Tin Herawati}

Department of Family and Consumer Sciences, Faculty of Human Ecology, Bogor Agricultural University

\begin{abstract}
Adolescence is a unique phase because at this stage the person becomes more independent, and togetherness intensity with peers increases at this stage. However, adolescent relationships with peers can affect positively or negatively on adolescent characters. This study aimed to analyze the effect of adolescent-peers communication and attachment on adolescent characters. The study was conducted in Pamijahan, Bogor Regency, involving 109 students of Vocational High School (SMK). Data were collected by using a modified instrument of the Parent-Adolescent Communication Scale, Adolescent Attachment Questionnaire and VIAYouth. Data were processed by using descriptive analysis and regression analysis. The results indicated high communication problem between adolescents and their peers. In addition, that was low openness among adolescents and their peers. The attachment between adolescents and their peers were also found low. The scores of rural adolescents character in this study were relatively low. It was allegedly associated with a low score of communication and attachment with peers. Results of regression analysis showed that only the attachment with peers has a significant effect on the scores of adolescent characters in rural.
\end{abstract}

Keyword :Adolescent, Attachment, Character, Communication, Peer Group

\begin{abstract}
Abstrak
Remaja merupakan fase yang unik karena pada tahap ini seseorang menjadi lebih mandiri dan intensitas bersama teman sebaya meningkat. Akan tetapi, hubungan remaja dengan teman sebaya dapat berdampak positif ataupun negatif terhadap karakter remaja. Penelitian ini bertujuan untuk mengetahui pengaruh komunikasi dan kelekatan remaja dengan teman sebaya terhadap perkembangan karakternya. Penelitian dilakukan di Kecamatan Pamijahan, Kabupaten Bogor dengan melibatkan 109 siswa Sekolah Menengah Kejuruan (SMK). Data diperoleh menggunakan instrumen yang dimodifikasi dari kuesioner Parent-Adolescent Communication Scale, Adolescent Attachment Questionnaire, serta VIA-Youtg. Data yang diperoleh diolah menggunakan analisis deskriptif dan analisis regresi. Hasil penelitian menunjukkan bahwa kualitas komunikasi antara remaja dengan teman sebayanya tergolong rendah. Hal tersebut dikarenakan masih tingginya permasalahan komunikasi serta rendahnya keterbukaan antar remaja dengan teman sebayanya. Selain itu, kelekatan antara remaja dan teman sebayanya juga ditemukan masih rendah. Skor karakter remaja di perdesaan pada penelitian ini tergolong rendah. Hal tersebut berhubungan dengan skor komunikasi dan kelekatan dengan teman sebaya yang rendah. Hasil uji regresi memperlihatkan bahwa hanya kelekatan dengan teman sebaya yang memiliki pengaruh signifikan terhadap skor karakter remaja di perdesaan.
\end{abstract}

Kata kunci : Karakter, Kelekatan, Komunikasi, Remaja, Teman Sebaya 


\section{Introduction}

Teen is one of unique development phases prompting many researchers to examine the developmental aspects in adolescents. There are things that characterize this phase, that is, decreasing the supervision of a parent due to the increased of independence and the emergence of the role of peers in influencing individuals development (Freeman and Brown 2001; Harris 1995; Berndt 1982). Research conducted by Selby (2000) also showed that adolescent attachment with peers play an important role in shaping the identity of the adolescene. Therefore, peers assume to influence, in any form of social support or peer pressure on adolescent development.

The problem of juvenile delinquency in Indonesia shows that the moral degradation has occurred in teenagers. The report from the Center for Data and Information Ministry of Health (2014) showed an increase trend in the number of crimes committed by an act of Indonesian teenages by 4.3 percent annually. In addition, the number of drug users in under 19 years also increased from 1891 people to 2238 people in 2012. This problems showed that the character of the Indonesian nation reflected in the actions of teenagers needs a special attention.

The problem of juvenile delinquency is found associated with adolescent relationships and their peers. That is because the adolescent relationships with peers can provide both of positive and negative impact. If the friendship that exists between teens and their peers are positive, it will affect social competence and ability to adapt in adolescents (Fass and Tubman 2002). However, peer pressure can also affect adolescents immoral behavior such as consumption of alcohol, premarital sex, to the act of bullying (Karina, Hastuti, and Alfiasari 2013). At this stage, adolescents and peer relationships become something important in every aspect of the development of individual adolescents themselves.

One study that captures the peculiarities of this adolescent phase is research of Meeus, Oosterwegel, and Vollebergh (2002), which examines the influence of communication and adolescent attachment with peers on the development of a person's identity. However, there is still little research that examines the influence of communication and attachment with peers on teenage characters overall.

The general objective of this study was to analyze the influence of communication and adolescent attachment with peers on adolescene characters. Furthermore, the specific objectives of this study consisted of: 1) identify the characteristics of adolescents, teens and peer communication, attachment with peers, and teenage characters; 2) analyze the relationship between characteristics of adolescents, communication and attachment with peers, and adolescents characters; 3) analyze the influence of the characteristics of adolescents, communication, and attachment with peers on adolescents characters.

\section{Research Method}

The design of this study was cross sectional study in two different vocational schools at Pamijahan district for two months. The choice of location in the research was 
done purposively based on data from one of the five largest regions representing the largest agricultural enterprises in Bogor Regency. Respondents in this study is vocational high school students selected in the Ciasihan and Ciasmara Village, Pamijahan subdistrict, Bogor. Total respondents numbered 109 students consisting of 44 girls and 65 boys with an average age of 16 years. Respondents were selected using proportional random sampling technique based on the location of the village and sex. Students as respondents were asked to fill out a questionnaire about the characteristics of adolescence, family characteristics, communication with peers, attachment with peers, and character.

Adolescent communication with peers was measured using an instrument developed from Parent-Adolescent Communication Scale (Barnes and Olson 1982). Total question for communication with peers variables measured by 18 questions with reliability 0.714 . Communication with peers consists of two dimensions: openness and problems in communicating. Examples of dimensions disclosure statement is "I find it easy to talk about my own problems with a friend". Examples of dimensions of the problem statement is "Sometimes I find it hard to believe what my friends said." Variable attachment with peers measured using a questionnaire developed from the Adolescent Attachment Questionnaire (West, Rose, Spreng, Sheldon-Keller and Adam 1998). The number of statements for variable attachment with peers consists of 15 items with reliability 0.637 . All of the question questionnaires use Likert scale 1-4 includes SS = Very Appropriate; S = Match; TS = Not Available; and STS = Very Not Available

Variables measurement of adolescent characters used a questionnaire developed from VIA-Youth of Peterson and Seligman (2004), which was developed using three dimensions of Lickona (1994), that is, moral knowing, feeling and action. Total of the questions for dimension of knowing numbered 21 items with reliability of 0848 . Furthermore, the dimensions of feeling, are 22 questions with the reliability of 0.775 . The last dimension is the dimension of action with the number of questions as many as 21 items with reliability 0.705 .

The scoring system is made to communicate with peers, attachment with peers, and characters using index formula. The categorization of variable communication with peers, attachment with peers, and the characters is divided into good/high and less/low. The categorization using the index of each variable used a cut off point either/high $(\geq 80 \%)$ and less/low $(<80 \%)$.

The analysis in the study used descriptive and inferential analysis consisting of Pearson correlation test and multiple linear regression tests were formulated as follows: $\mathrm{Y}=\mathrm{a}+\mathrm{b} 1 \mathrm{x} 1+\mathrm{b} 2 \mathrm{X} 2+\mathrm{b} 3 \mathrm{X} 3+$ $+\mathrm{B} 4 \mathrm{X} 4$

Information:

$\mathrm{Y}=$ Adolescent Character

a $=$ Constant

$\mathrm{X} 1=\operatorname{Sex}(0=$ Female, $1=$ Male $)$

$\mathrm{X} 2=$ Adolescent Age (Years)

$\mathrm{X} 3=$ Communication with Peers (Index)

$\mathrm{X} 4=$ Attachment with Peers (Index) 


\section{Result}

\section{Characteristics of Adolescent and Family}

Teenagers who were respondents in this study consisted of 44 girls and 65 boys with ages ranging from 15 to 19 years. According to Santrock (2007), that age is at the stage of late adolescence. The average age of the father and the mother's age in the category of middle age is 47 years, with an age ranges from 30 to 75 years. Furthermore, the father and mother's education level is low with average both for five years. It shows that the average parent does not pass the elementary school.

Table 1 Rated minimum, maximum, average, and standard deviation of the characteristics of youth and families

\begin{tabular}{lccc}
\hline $\begin{array}{l}\text { Characteristics of Adolescence and } \\
\text { Family Values }\end{array}$ & $\begin{array}{c}\text { Minimum } \\
\text { Values }\end{array}$ & Maximum Values & Mean \pm SD \\
\hline Adolescent age (years) & 15 & 19 & $16.89 \pm 0.85$ \\
Paternal age (years) & 31 & 75 & $47.38 \pm 8.32$ \\
Maternal age (years) & 30 & 73 & $42.06 \pm 7.64$ \\
Father's education (years) & 0 & 12 & $5.77 \pm 2.12$ \\
Mother's education (years) & 1 & 12 & $5.60 \pm 1.95$ \\
Income per capita per month & 27.778 & 2.000 .000 & $420.718 \pm$ \\
(rupiah) & & & 413.191 \\
\hline
\end{tabular}

In 2013, the poverty line standard of Bogor Regency was Rp 271.970. Although parental educational level is low, the average of income per capita per month of the family is still higher than the poverty line in Bogor regency in 2013 amounting to Rp 420.718. However, half of the total respondents $(52.3 \%)$ is still quite poor

\section{Communication with Peers}

Adolescent and peers communication were measured by two dimensions: openness and communication problems. The results showed that almost all of respondents $(97.2 \%)$ are still in the low category to the variable communication with peers. The average score of adolescent communication and the parent is at 57.17 with a range of scores 37.04 until 88.89. Figure 1 shows that communication between adolescents with their peers did not go too well. Communication problems experienced by adolescents with their peers is still high. Almost all respondents in the study (98.2\%) had problems in communicating with their peers. There were respondents who stated that a friend once said something that was not supposed to talk to them.

Teens hard to believe what a friend said. There are also friends insulting or saying inappropriate when they are angry. Not only that, the communication problems are also evident from the level of disclosure of teenagers in communicating with their peers categorized as lower level. Teens are still difficult to say what they want to say to her friend. There are things that are considered embarrassing to talk about to their peers. Not only that, teens also stated that they never get an honest answer when they ask peers. 


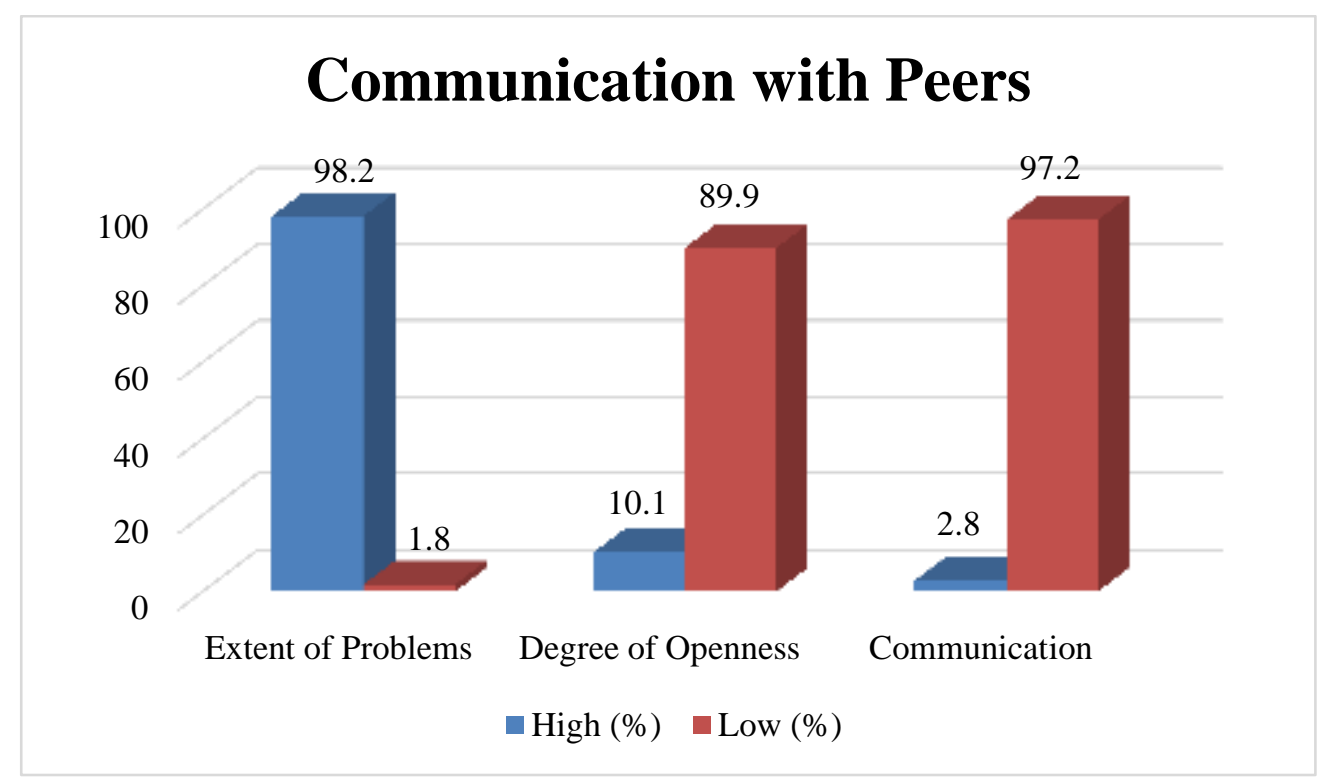

Figure 1 Teens distribution by category of communication to their peers.

\section{Attachment with Peers}

Table 1 shows that the average score of adolescent attachment with peers is at 62.43. A total of 92.7 percent of the total respondents have a low attachment with their peers. Adolescent attachment with peers score in the study ranged from 35.56 until 88.89. The result analysis of the questions showed that more than half of the respondents, or as much as 86.3 percent of teens often feel angry with her without no apparent reason. Instead, only a few of the respondents $(22 \%)$ who say never let down by his friend. Sense of disappointment and anger showed that the attachment that exists is not very good. Some respondents also stated that they did not believe that their friend will always be there and listen to their concerns. That is because when a teenager in trouble they can not rely on their friends.

Table 1 Distribution of adolescents by category attachment with peers

\begin{tabular}{|c|c|c|}
\hline Attachment with peer & $\mathrm{n}$ & $\%$ \\
\hline Low $(<80 \%)$ & 101 & 92.7 \\
\hline $\operatorname{High}(\geq 80 \%)$ & 8 & 7.3 \\
\hline $\operatorname{Min}-\max$ & & \\
\hline Mean \pm sd & & \\
\hline
\end{tabular}

\section{Adolescent Character}

Table 2 shows that the highest average scores of the character of the threedimensional were in the knowledge dimension (84.48). In contrast, the average score on 
the dimension of moral action performed only teenagers was at 64.74, in other words, it's low. The results of this study show that almost all teenagers $(91.7 \%)$ stated that the cleanliness of the school is the responsibility of the entire school community. In fact, 61.5 percent of the total respondents did not join voluntary work in schools. It shows that adolescents know which actions are good or bad, but not necessarily the teen did not do a bad action. While the overall character score was only 73.93, in other words, it's good (Table 2).

Table 2 Score of minimum, maximum, average, and standard deviation of character

\begin{tabular}{lccc}
\hline Character & Minimum Value & Maximum Value & Mean \pm SD \\
\hline Knowing & 52.38 & 100.00 & $84.48 \pm 8.43$ \\
Feeling & 50.00 & 92.42 & $72.57 \pm 8.94$ \\
Action & 39.68 & 85.71 & $64.74 \pm 9.62$ \\
\hline Character Total & 48.94 & 91.68 & $73.93 \pm 7.64$ \\
\hline
\end{tabular}

\section{Factors Associating with Adolescent Character}

The results showed that gender significantly associated with all dimensions of teenage characters. Table 3 shows that adolescent girls scored better on every dimension of character than boys. Adolescent age is negatively related to a person's moral knowledge. Younger teens in the study had a moral knowledge score higher than older teens.

Table 3 The correlation coefficient between the characteristics of adolescent, families, attachment, and teenagers peers communication with teenage characters

\begin{tabular}{lcccc}
\hline \multirow{2}{*}{ Variable } & \multicolumn{4}{c}{ Correlation Coefficient } \\
\cline { 2 - 5 } & Moral Knowing & Moral Feeling & Moral Acting & Character Total \\
\hline Sex (0=female, 1=male) & $-.265^{* *}$ & $-.228^{*}$ & $-.246^{* *}$ & $-.289^{* *}$ \\
Age (years) & $-.193^{*}$ & -.087 & -.124 & -.157 \\
Peer Communication & $.363^{* *}$ & $.494^{* *}$ & $.336^{* *}$ & $.467^{* *}$ \\
(score) & $.481^{* *}$ & $.546^{* *}$ & $.438^{* *}$ & $.574^{* *}$ \\
Peer attachment (score) & & & & \\
\hline
\end{tabular}

Information: *Significant at $\mathrm{p}<0.05 ; * *$ Significant at $\mathrm{p}<0.01$

Aside from the characteristics of adolescent, communication and adolescent attachment with peers were found positively associated with all dimensions of adolescent characters, that is, if the communication between teenagers and peers open with each other and avoid the problem of adolescent characters, the score of adolescent character will be better. In addition, teens who had good attachment with peers have a better character index. Descriptive analysis in this study showed that the scores of communication and adolescent attachment with their peers associated with lower overall scores teenage characters that are also low. 


\section{Factors Affecting Adolescent Character}

The results showed that the characteristics of adolescent consisting of gender and age did not have a significant effect on each dimension of adolescent characters and overall. The regression analysis presented in Table 4 shows that only adolescent attachment with peers that affects any moral dimension as well as the overall positive character. This can occur because during adolescence period, peers have a major influence in shaping the character and personality of the adolescent (Berndt 1982). The ability to build positive attachment with peers will encourage adolescent to develop positive things about them. The model built in this study may explain its effect on adolescent characters by 32.7 percent. The rest can be explained by other variable, for example adolescent relationships with parents.

Table 4 The results of multiple linear regression analysis the variables that affect the character of teenagers

\begin{tabular}{|c|c|c|c|c|c|c|c|c|}
\hline \multirow[t]{2}{*}{ Variable } & \multicolumn{2}{|c|}{ Moral Knowing } & \multicolumn{2}{|c|}{ Moral Feeling } & \multicolumn{2}{|c|}{ Moral Acting } & \multicolumn{2}{|c|}{ Character Total } \\
\hline & $\beta$ & Sig. & $\mathrm{B}$ & Sig. & $\beta$ & Sig. & $\beta$ & Sig. \\
\hline Constant & 73.085 & .000 & 32.920 & .048 & 41.853 & .031 & 49.286 & .001 \\
\hline $\begin{array}{l}\text { Sex }(0=\text { female, } \\
1=\text { male })\end{array}$ & -2.196 & .174 & -1.366 & .400 & -2.705 & .154 & -2.089 & . 126 \\
\hline Age (years) & -.570 & .526 & .498 & .583 & .075 & .943 & .001 & 999 \\
\hline $\begin{array}{l}\text { Peer } \\
\text { Communication } \\
\text { (score) }\end{array}$ & .010 & .918 & .166 & .106 & .013 & .912 & .063 & .461 \\
\hline $\begin{array}{l}\text { Peer Attachment } \\
\text { (score) }\end{array}$ & .384 & $.001 * *$ & .383 & $.001 * *$ & .404 & $.003 * *$ & .390 & $.000 * *$ \\
\hline $\begin{array}{l}\text { Adjusted R } \\
\text { Square } \\
\end{array}$ & \multicolumn{2}{|c|}{.226} & \multicolumn{2}{|c|}{.300} & \multicolumn{2}{|c|}{.179} & \multicolumn{2}{|c|}{.327} \\
\hline
\end{tabular}

Description: * significant at $\mathrm{p}<0.05 ; * *$ Significant at $\mathrm{p}<0: 01$

\section{Discussion}

Adolescent relationships with peers is a relationship that is often used as a spotlight in adolescence period. Decreasing supervision from parents and increasing closeness with peers are a hallmark of adolescent phase. Adolescent relationships with peers are often linked to negative things. However, positive friendships between teenagers with their peers can have a positive impact, like reducing the level of juvenile delinquency and adolescent stress levels (Hair, Jager, and Garrett 2002). This study found that adolescents in rural communication established with peers are still relatively low. Adolescents in rural areas still have high problems of communicating with their peers. The low quality of communication between teenagers and peers may be caused by various factors. Nurture factor that is not going well can make adolescent have 
trouble to building a close and led to the difficulty of interacting with one of the social environment's peers (Dodge and Gonzales, 2009).

In line with the communication scores that were low, peer attachment remains low. Less exposure of adolescents communication and there are still problems, such as mutual communication with friends chided cause adolescents less attached to their peers. In addition, the communication did not go wel. The low attachment can be caused by experience of attachment with bad parenting. Good attachment with parents affects the ability of adolescents in building attachment with others e.g. peers. Therefore, the findings of this study can be explained by the study of the Waters, Hamilton, and Weinfield (2000) stating that the attachment is formed by a parent at an early age that will be stable until adolescence and even adulthood. Therefore, it is alleged that the juvenile study who has experience poor attachment with parents that have an impact to their teens.

The results showed that the gender and age of adolescence are associated with a moral dimension. It was found that the character of adolescent girls is better than that of the boys. This is consistent with the findings Karina et al. (2013) and Dewanggi et al. (2014). However, the difference in character between adolescence girls and adolescence boys is because adolescence girls are usually more sensitive on matters related to feelings than boys (Lerner and Steinberg 2004). Adolescence is also negatively related to moral knowledge. It was found that adolescents with younger age have a moral knowledge that is better than older adolescents.

Berndt (1982) stated that in the adolescent phase, friendship becomes the determining factor to almost every aspect of teenage life both social and personality. Good communication and without conflicts with peers were found to affect the moral feelings of a teenager. The study reinforces the findings of Berndt (2002) which states that the quality of friendship will improve the attachment, prosocial behavior, as well as many other positive examples of moral feelings of a teenager. However, in this phase adolescents are also susceptible to the influence of peer pressure. Especially when peer pressure leads to pressure on the negative things. If teens are too attached to their peers, so they have a tendency to follow whatever peers do. If this is done so, it can be received by the friend because it is very important for young people to be able to feel welcome by the environment of friendship. However, if adolescence get wrong to choose friendship neighborhood, then he will follow the bad things done by his friends. That is because when teens spend a lot of time with peers unconsciously, he will do what his friend did (Santrock 1996).

In addition to the above studies, many research that highlights the influence of attachment to peers on adolescent development (Zimmermann, 2004; Freeman and Brown 2001; Fuligni and Eccles 1993). This study itself found that attachment with peers affects every aspect of his character in a positive way. In general, research Chassin et al. (1986) and Rosenthal \& Kobak (2010) found that attachment with peers can predict adolescent problem behaviors that owned by adolescene. However, in this case a positive attachment with peers can improve knowledge, feelings, and positive action undertaken by a teenager. This can be explained by the research of Thomas (2011) who found that negative behavior from the neighborhood will not affect the 
behavior of adolescents if they have a positive attachment with peers. In general it can be said that in this study as well as the attachment poor communication with peers making teenage characters overall score is still low. The model built in this study can only explain the effects on the development teenage characters of 32.7 percent. This shows the contribution of other factors in the development of teenage characters. Samples of peer pressure not examined in this study were peer pressure. Peer pressure affected behavior and teenage characters (Soetjiningsih 2007). According to Bronfenbrenner systems theory approach, the development of a person is not only influenced by the system but this can also be influenced by other systems. In this case, the development of a person's character can be influenced by parents, school, peers, or siblings (Bronfenbrenner and Morris 2006)

\section{Conclusion and suggestion}

\section{Conclusion}

Communication and attachment with peers are low in rural adolescents. Low moral knowledge was found in older adolescents and low quality of communication with peers. Adolescence girl characters; moral knowledge, moral feeling, and moral action were found to be better than those of the boys. Ineffective communication and a low attachment with peers also make lower adolesnce characters in every dimension. Characters adolescents are highly influenced by attachment to peers. If the attachment interwoven with peers is good, the characters formed is also good.

\section{Suggestion}

The results of this study are expected to be a reference to the relevant institutions to assist and provide information to the youth and parents in rural areas. Bogor regency administration is expected to pursue cooperation with KPAI and BKKBN to provide counseling to the youth in order to avoid the influence of peers who are not good. In addition, the teens should be given a briefing on how to deal with problems in the juvenile phase. This can be done to help teens who have less information and assistance from parents in rural areas. The government is also expected to accompany parents to supervise and oversee the youth in their interaction with their peers.

\section{Reference}

Barnes HL, Olson DH. 1982. Parent-adolescent communication scale. St. Paul: Family Social Science, University of Minnesota

Berndt TJ. 1982. The features and effect of friendship in early adolescence. Child Development 53

Berndt TJ. 2002. Friendship quality and social development. Current Directions in Psychological Science 11(1)

[BPS] Central Bureau of Statistics. 2013. Data and information poverty Regency / City in 2013 [Internet]. [Downloaded 2015 Sept 01]. Available at: www.bps.go.id. 
Bronfenbrenner U, Morris PA. 2006. The Bioecological Model of Human Development. US: John Wiley \& Sons Inc.Bronfenbrenner U, Morris PA. 2006. The Bioecological Model of Human Development. US: John Wiley \& Sons Inc.

Chassin L, Presson CC, Sherman SJ, Montello D, McGrew J. 1986. Changes in peer and parents influence during adolescence: Longitudinal versus cross-sectional perspectives on smoking initiation. Developmental Psychology 22 (3)

Data center and the Ministry of Health information. 2014. Say no to drugs: Say yes to life [Internet]. [Downloaded in 2015 Mar 25]. Available at: http://www.depkes.go.id/resources/download/pusdatin/infodatin/infodatin-antinarkoba.pdf.

Dewanggi M. 2014. Influence of attachment, parenting style, and environmental quality child care to rural and urban character [thesis]. Bogor: Study Program of Family and Child Development, Bogor Agricultural University

Dodge K, Gonzales N. 2009. Family and peer influences on adolescent behavior and risk-taking. Paper presented at IOM Committee on the Science of Adolescence Workshop, Washington, DC.

Fass ME, Tubman JG. 2002. The influence of parental and peer attachment on college students' academic achievement. Psychology in the Schools 39(5). Doi: 10.1002/pits. 10050

Freeman H, Brown BB. 2001. Primary attachment to parents and peers during adolescence: Differences by attachment style. Journal of Youth and Adolecence 30(6)

Fuligni AJ, Eccles JS. 1993. Perceived parent-child relationship and early adolescents' orientation toward peers. Developmental Psychology 29(4)

Hair EC, Jager J, Garrett SB. 2002. Helping teens develop healthy social skills and relationships: What the research shows about navigating adolescence. Child Trends Research Brief

Karina, Hastuti D, Alfiasari. 2013. The behavior of bullying and teenage characters and their relationship with the family and peer group characteristics. Journal of Family and Consumer Sciences 6 (1).

Lerner RM, Steinberg L. 2004. Handbook of Adolescent Psychology. New Jersey: John Wiley \& Sons, Inc.

Lickona T. 1994. Raising Good Children. Amerika (US) : Bantam Books.

Meeus W, Oosterwegel A, Vollebergh W. 2002. Parental and peer attachment and identity development in adolescence. Journal of Adolescence 25

Peterson C, Seligman MEP. 2004. Character Strengths and Virtues: A Handbook and Classification. New York: Oxford Univrsity Press

Rosenthal NL, Kobak R. 2010. Assesing adolescents' attachment hierarchies: Differences across developmental periods and associations with individual adaptation. Journal of Research on Adolescence

Santrock JW.1996. Adolescence. New York: McGraw-Hill

Santrock JW. 2007. Life-span Development. New York: McGraw-Hill

Selby JC. 2000. The relationship of parental attachment, peer attachment, and selfconcept to the adjustment of first-year college students [Disertasi]. Texas: University of North Texas 
Soetjiningsih $\mathrm{CH}$. 2007. The parent-teenager relationships and self-esteem as a predictor of peer pressure on adolescents [thesis]. Christian University Satya Discourse. Yogyakarta

Waters E, Hamilton CE, Weinfield NS. 2000. The stability of attachment security from infancy to adolescence and early adulthood: General introduction. Child Development 71(3)

West M, Rose SM, Spreng S, Sheldon-Keller A, Adam K. 1998. Adolescent attachment questionnaire: A brief assessment of attachment in adolescence. Journal of Youth and Adolescence 27(5)

Zimmermann P. 2004. Attachment representations and characteristics of friendship relations during adolescence. Journal Experimental Child Psychology 88 